\title{
Designing international tax reform: lessons from TCJA
}

\author{
Mindy Herzfeld ${ }^{1} \mathbb{C}$
}

Accepted: 28 May 2021 / Published online: 30 June 2021

(c) The Author(s), under exclusive licence to Springer Science+Business Media, LLC, part of Springer Nature 2021

\begin{abstract}
The Tax Cuts \& Jobs Act (TCJA) introduced the most significant changes to the US international tax system in decades. The law changes have been criticized for reducing equity, benefiting wealthier business owners at the expense of individuals in the long term (while also increasing the deficit) adding to complexity, and creating incentives for shifting profits and activities offshore. These critiques give rise to the question of how best, and under what criteria, to evaluate the changes to the international tax system brought about by the US tax reform. This paper analyzes the tax law changes adopted in the TCJA that impact cross-border investment within the context of several decades of policy proposals that recognized the flaws and deficiencies of the prior system and attempted to develop proposals that balanced creating incentives for the efficient use of capital and the benefits of US investment overseas while minimizing incentives for profit shifting. Reviewing the various provisions of the law in the context of a series of reform proposals made over the previous decade shows the extent to which most of the international law changes introduced by the TCJA closely followed these well-developed ideas. And yet, there appears to be a disconnect between the goals of the law change and the extent to which the laws as enacted have effectuated that change. The divergence provides a cautionary tale for public finance economists wishing to engage in international tax regime change.
\end{abstract}

Keywords International tax · Tax reform · Profit shifting $\cdot$ Cross-border investment

JEL Classification K34 $\cdot$ P48 $\cdot$ F23

Mindy Herzfeld

herzfeld@law.ufl.edu

1 University of Florida Levin College of Law, Gainesville, FL, USA 


\section{Introduction}

In 2017, the USA passed a major international tax reform as part of the enactment of the Tax Cuts \& Jobs Act (TCJA). ${ }^{1}$ The law has been subject to critiques from all sides, with commentators criticizing the law for reducing equity, benefiting wealthier business owners at the expense of individuals and adding to complexity and tax planning opportunities, while also increasing the deficit (Avi-Yonah, 2018; Kamin, 2018; Kleinbard, 2017; Kysar, 2018, 2020; MacGuineas, 2019). And yet, the international provisions of the law were largely modeled on and bear close resemblance to widely circulated international tax reform ideas as well as proposals introduced by the OECD as part of its base erosion and profit shifting project (OECD, 2013). Most notably, the US international tax reforms introduced by the TCJA closely parallel ideas included in a proposal for international tax reform laid out in a formative 2013 paper by Harry Grubert and Roseanne Altshuler (Grubert \& Altshuler, 2013). The disconnect between their ideas, which built on more than a decade of thinking and research and formed the basis for the next iteration of proposals, and the results of the law passed by the U.S. Congress in 2017 , provides a cautionary tale for public finance economists.

This paper analyzes the tax law changes adopted by the TCJA that impact crossborder trade and investment by measuring them against goals for international tax reform that were widely agreed upon (on a bipartisan basis) prior to enactment. It finds that while the goals for the reform may have been based in well-accepted fiscal policy, the law changes seem to have fallen far short of the anticipated results. Most importantly, the new system did not eliminate the obstacles from either primarily tax-motivated planning or the tax preferences for overseas investment relative to domestic investment, and probably did not level the playing field between US and foreign multinationals. The gap between principle and practice can be attributed at least in part to a combination of rushed drafting as well as insufficient appreciation of how the complex rules would interact with each other as well as existing law. The partisan manner in which the law was enacted played a role in maintaining tax distortions, as it increased rather than decreased the uncertainty associated with the decision to invest domestically rather than overseas.

The paper proceeds as follows. Part I briefly summarizes the existing literature on the goals of international tax reform as compared with well-accepted metrics in the domestic area. It then outlines the goals of tax reform articulated by Republican administration and congressional leadership in the lead-up to the passage of the TCJA. Part II outlines various international tax reform proposals made in the decade leading up to the 2017 tax reform, and the metrics developed by Grubert and Altshuler for evaluating the merits of different proposals. Part III analyzes the international provisions of the TCJA in terms of what they were intended to do and their results insofar as they can be evaluated to date. Part IV concludes.

\footnotetext{
1 The official name is "The Act to provide for reconciliation pursuant to titles II and V of the concurrent resolution on the budget for fiscal year 2018.” Pub. L. No. 115-97, 131 Stat. 2054.
} 


\section{Goals of tax reform}

\subsection{Tax reform goals: domestic and international}

Tax systems are generally measured relative to goals including revenue maximization, equity, efficiency, administrability, simplicity and stability (Avi-Yonah, 2006; Slemrod \& Bakija, 2017). But there is no theoretical ideal against which to evaluate international tax rules, partly because it is not clear how to translate concepts of equity and efficiency into a cross-border context. Domestic public finance goals of maximizing national welfare and redistributing wealth don't translate well into the international context (Christians, 2018). The domestic public finance goals of maximizing national welfare while achieving the redistributional purposes of the tax system are generally absent once public finance moves to the international context (Graetz \& O'Hear, 1997). Without an agreed upon set of goals, it is hard to develop optimal tax rules (Keen \& Wildasin, 2004). As a consequence, international tax rules generally are measured primarily based on the extent to which they minimize distortions in cross-border investment and use of capital (Mirlees, 2011; Joint Committee on Taxation, 2011; Minarik, n.d.).

Optimal design of international tax rules has traditionally been described within the framework of two competing policy goals (Musgrave, 1969; Richman, 1963). While capital export neutrality (CEN) focuses on efficient global allocation of capital, capital import neutrality (CIN) is supposed to reduce inefficiencies in the structuring of cross-border investments (Avi-Yonah, 2005; Knoll, 2011). More recent scholarship articulates other types of "neutralities," including national neutrality (which prefers domestic investment to foreign investment) (Frisch, 1990; Graetz, 2001; Weisbach, 2015) and ownership neutrality (which argues that optimizing ownership neutrality is more efficient than other paradigms), to describe different competing considerations in the design of international tax rules (Desai \& Hines, 2003, 2004; Devereux, 2008; Kane, 2006; Shaviro, 2016). Others question the premise of "neutralities" as the proper goal altogether (Weisbach, 2015).

In the absence of any principled theory to justify a particular set of policies or rules, a combination of foreign policy goals, competitiveness, domestic economic growth and fiscal objectives necessarily take their place. Without agreement on goals and metrics, there's no obvious way to evaluate the merits of a country's international tax system (Herzfeld, 2017).

\subsection{Goals of TCJA}

The TCJA was passed along party lines, and some of its stated goals had a different focus from the objectives that are economists' primary focus. The Republican led Congress and administration identified a number of principal objectives for tax reform both before and after the 2016 election. ${ }^{2}$ Foremost among these were

\footnotetext{
2 See, e.g., Jonathan Curry and Stephen Cooper, Trump and GOP Outline Paths to 2017 Tax Reform, 153 Tax Notes 1400, 1400 (Dec. 19, 2016) (quoting Senate Majority leader Mitch McConnell as saying that tax reform would "encourage US businesses to keep jobs in America rather than move abroad for tax relief').
} 
economic growth, job creation, ensuring the competitiveness of US businesses relative to foreign businesses, protecting American jobs, and encouraging businesses to retain manufacturing assets and intellectual property in the USA (Stecker, 2018). ${ }^{3}$ Speeches and policy papers also emphasize the need to protect the US tax base from erosion by and to other countries. A third objective often expressed was simplification (Beavers, 2017; Guild, 2017).

The Unified Framework on Tax Reform released by the administration and congressional leadership shortly before the TCJA's passage articulated the White House and Congressional leadership's goals for achieving "pro-American, fiscally-responsible tax reform," defined as making the tax code simple, fair and easy to understand, giving American workers a pay raise by allowing them to keep more of their hard-earned paychecks, making America the jobs magnet of the world by leveling the playing field for American businesses and workers, and bringing back trillions of offshore dollars to reinvest in the American economy (Treasury Department, 2017). In addition to the strong emphasis on US economic interests and protection of the US tax base, the Unified Framework committed to putting an "end to the incentives for shipping jobs overseas." It proposed to achieve these goals by taxing at a reduced rate and on a global basis the foreign profits of US multinationals, and said that congressional tax-writing committees would "incorporate rules to level the playing field between U.S.-headquartered parent companies and foreign-headquartered parent companies."

The focus on tax reform as a tool to advance economic growth is also evident in a Republican tax reform blueprint released in June 2016, which focused on using the tax code to address the problems of slow growth, declining labor force participation, flat productivity, and weak investment (A Better Way, 2016). The proposal emphasized its commitment to "an efficient tax code that interferes as little as possible with the growth of businesses and preserves the value of work for individuals." 4 The blueprint proposed replacing the US worldwide tax system with a 100-percent exemption for dividends from foreign subsidiaries to eliminate the lockout effect by permitting US-headquartered companies to bring home their foreign earnings for US investment without extra tax.

\footnotetext{
3 See, e.g., KPMG, Legislative update: Comprehensive tax reform in 2017, predicts Brady (Nov. 15, 2016) https://home.kpmg/us/en/home/insights/2016/11/tnf-legislative-update-comprehensive-tax-reformin-2017-predicts-brady.html (quoting Ways \& Means Chairman Kevin Brady as emphasizing that tax reform "would focus on economic growth (growth in both jobs and wages) and 'leapfrog' the US to a leadership position for those making global investments.").

${ }^{4}$ See Brady Opening Statement at Tax Cuts \& Jobs Act Conference Committee Meeting, 2017 TAX Notes TodAy 239-36 (Dec. 13, 2017) ("we insisted on designing one of the most competitive tax systems in the world-for the American people"). Chloe Aiello, Ways and Means Chairman Kevin Brady: 'We've got the fundamentals right in this tax reform bill', CNBC (Dec. 21, 2017), https://www.cnbc. com/2017/12/21/rep-kevin-brady-on-tax-reform-weve-got-the-fundamentals-right.html (quoting Brady as saying that "the tax bill encourages companies to re-invest in America and gives American companies an upper hand in the global market"). See also Sen. Fin. Comm., Tax Reform Gets Rave Reviews: What They're Saying (Mar. 2, 2018), https://www.finance.senate.gov/chairmans-news/tax-reform-gets-ravereviews-what-theyre-saying (quoting Senate Finance Committee Chairman Orrin Hatch for the proposition that "Long story short: America is competitive again.").
} 
Various iterations of the need to make changes to US international tax rules to protect the competitiveness of US businesses and the US tax base were prevalent in proposals developed by both Democrats and Republicans over the prior decade (Grinberg, 2017; Grubert \& Altshuler, 2013).

\section{Designing international tax reform}

In his 40-year tenure at the U.S. Treasury's Office of Tax Analysis, Grubert (who passed away in August 2017, just a few months before passage of the Tax Cuts \& Jobs Act) wrote numerous papers-on his own and collaboratively with other economists - that collectively represent a comprehensive analysis of practically every concern raised since the 1980 s about the US international tax rules. Together with Altshuler, he wrote a number of papers analyzing data on multinationals' cross-border taxes and developing proposals for addressing the problems that this data revealed. Their 2013 paper (Grubert \& Altshuler, 2013) which represented the culmination of that work, evaluated a number of the international tax reform proposals then being considered among policy makers, academics, and legislators against a well-articulated set of design principles. The problems they identified, which included both tax avoidance concerns and incentives inconsistent with the goal of increasing US investment, were widely recognized and the solutions they proposed largely found their way into the law passed in 2017, making their 2013 paper a unique vehicle against which to evaluate the TCJA's international tax law changes.

\subsection{The problems to be solved}

In the years prior to enactment of TCJA, it was generally recognized that US international tax rules needed to be reformed to address a number of widely acknowledged problems.

\subsubsection{Lockout}

It was widely accepted that pre-TCJA rules incentivized US multinationals to keep their foreign earnings offshore rather than repatriating them to the USA (generally referred to as "lockout"). The consequences of a set of rules that allowed shareholders of controlled foreign companies (CFCs) to defer paying cash taxes and accruing US income tax for financial statement purposes on CFC earnings, while imposing high taxes upon repatriation, have been extensively documented (Blouin et al., 2017; Edwards et al., 2016; Sullivan, 2012). Under pre-2017 rules, US companies were able to access offshore cash through various means including loans, but doing so increased the cost of capital and created incentives for US multinationals to pursue foreign rather than domestic acquisitions (Grubert \& Altshuler, 2013). Lockout was a problem that both increased tax-motivated planning but also had real effects on cross-border investment decisions. 


\subsubsection{Income shifting}

Pre-TCJA tax rules permitted and even encouraged both US- and foreign-headquartered multinationals to shift income away from the US tax base; US tax rules also encouraged foreign-to-foreign income shifting by US multinationals (Clausing, 2011; De Mooij \& Ederveen, 2008; Hines, 1999; Kleinbard, 2011a). Grubert and Altshuler argued in 2013 that income shifting was a pervasive problem and getting worse, a problem that they partially blamed on the tax planning opportunities provided by US check-the-box (CTB) regulations adopted in 1996 that facilitated foreign tax planning (Grubert, 2012; Kleinbard, 2011b). These rules were considered to have exacerbated the tax distortions in multinationals' investment decisions by increasing tax benefits from shifting profits to low-tax jurisdictions (Keightley, 2013; Offshore Profit Shifting and The U.S. Tax Code, 2013; Kleinbard, 2011a). The ease and prevalence of income shifting became a public fairness issue as the media seized on the topic as part of the post-financial crisis publicity over fair taxation, concerns over which ultimately led to the 2013 launch of the OECD's base erosion and profit shifting project (Avi-Yonah \& Xu, 2017; Gravelle, 2017; OECD, 2013). While income shifting is primarily a problem of tax planning, it also can influence substantive operations as, for example, the decision to locate intellectual property in a given location could bring jobs along with it.

\subsubsection{Complexity}

The complexity of the US tax system, especially as related to cross-border income, is well known, and while partly due to the economy's complexity, also is attributable to Congress' inclination to use tax rules to incentivize (or disincentivize) social behavior and achieve specific economic goals, its tendency to enact temporary tax measures (for budget projection reasons), frequent law changes, and enactment of broad statutes that require implementing regulations. Layered on to these challenges is the interaction of federal tax laws with state and foreign laws and tax treaties (Joint Committee on Taxation, 2015). Additional complications unique to the international tax rules are derived from the foreign tax credit calculations, which limit creditability to the US tax on foreign-source income and as part of the process require the allocation of expenses between foreign and domestic gross income and between different baskets of income. The US antideferral (subpart F) rules have always been complex, a problem multiplied by the existence of potential applicability of more than one anti-deferral regime (the personal foreign investment corporation (PFIC) rules, subpart F rules and foreign personal holding company rules). In the inbound context, other notable pre-TCJA complexities included the interest expense limitation rules, the branch profits tax, and the existence of different sets of statutory and treaty rules governing taxation of foreigners doing business in the USA. Overarching the system of technical legal rules is another type of regime based on economics rather than legal principles: the arm's length standard of transfer pricing. 


\subsubsection{Competitiveness}

The pre-TCJA US tax rules were widely perceived as providing greater incentives for investment in low-taxed foreign locations than in the USA, or even in highertaxed jurisdictions that allowed for foreign-to-foreign base erosion opportunities. The additional tax imposed on repatriation of foreign earnings was viewed as discouraging real investment in the USA as well as leading to inefficiencies in the worldwide allocation of capital (Grubert \& Altshuler, 2013). Concerns over competitiveness reflect concerns over location decisions for real investment.

\subsection{A history of design proposals}

\subsubsection{Pre-2013 proposals}

Academics and legislators had been working on and proposing different ideas for major reform of the US international tax rules practically since the enactment of the last major US tax reform in 1986 (Joint Committee on Taxation, 2013; Gravelle, 2015; The Bipartisan Tax Fairness and Simplification Act of 2011 (S. 727) Corporate Tax Fairness Act, 2013). In 2001, Grubert and Mutti laid out a proposal for a US dividend exemption or territorial system, arguing that such a regime would remove the incentives to keep earnings locked overseas and the disincentives for investing in the USA (Grubert \& Mutti, 2001; Herzfeld, 2018a). A 2005 presidential tax reform advisory panel broadly adopted Grubert and Mutti's recommendations and proposed exempting dividends paid from the active earnings of CFCs and foreign branches from US tax and reducing the top corporate tax rate from 35 to 31.5 percent (Advisory Panel Report, 2005). The panel also suggested disallowing deductions attributable to expenses incurred in generating exempt foreign earnings.

In a 2008 paper, Grubert and Altshuler (who served as senior economist on the 2005 panel) analyzed the effects of US adoption of a dividend exemption system similar to that proposed by the panel, relative to a system that eliminated deferral but required no expense allocation to foreign income (Grubert \& Altshuler, 2008). To address competitiveness concerns and reduce incentives for income shifting, they suggested combining worldwide taxation with a reduced rate on foreign-source income, and a significant reduction in the corporate rate to approximately $28 \%$.

In 2011, House Ways and Means Committee Chair Dave Camp released a discussion draft of comprehensive reform that included a proposal for a 95 percent dividends-received-deduction (DRD) for qualified foreign-source dividends from CFCs received by corporate 10 percent US shareholders, with no foreign tax credits available (Ways \& Means Discussion Draft, 2011). Camp also proposed reducing the corporate rate to 25 percent, as well as three alternative proposals for expanding subpart $\mathrm{F}$ income to address base erosion concerns that become more pronounced in a territorial system. The third alternative was a proposal for a 
vastly expanded taxation of CFC earnings at a lower rate on what was referred to as "foreign base company intangible income," plus a partial deduction for intangible income earned in the USA. Camp also proposed to disallow a portion of the US parent company's net interest expense.

In 2012, Republican Senator Enzi introduced a bill with international reforms similar to Camp's 2011 proposals (S. 2091), including a 95 percent dividend exemption. It also would have subjected the accumulated earnings of CFCs to current US tax under one of two alternative regimes per the taxpayers' choice-either a $70 \%$ exclusion with no foreign tax credits allowed, or full taxation with a foreign tax credit allowed when the earnings were paid as dividends. The Enzi bill included anti-base-erosion provisions that would have subjected to current US tax under the subpart $\mathrm{F}$ rules income earned in countries with tax rates of no more than half the US rate, with an exemption for active business income. Domestic companies' intangible income would be eligible for a reduced $17.5 \%$ rate.

The Obama administration also proposed various international tax reforms. Its 2012 framework for business tax reform included proposals for a minimum tax (of 19 percent) on foreign earnings, with an 85 percent foreign tax credit calculated on a per-country basis, and an allowance for corporate equity that essentially provided a risk-free return on active assets (Sherlock, 2013; U.S. Department of Treasury, 2013). Democratic Senator Baucus released a discussion draft on international tax reform in 2013, which proposed to tax passive and highly mobile income at full US rates when earned, while taxing income from products and services sold into foreign markets under one of two alternative systems at a reduced rate with allowance for foreign tax credits, along with a full exemption for foreign earnings upon repatriation (U.S. Senate Committee on Finance, 2013). Interest deductions for domestic companies would be limited to the extent their foreign earnings were exempt from US tax and their domestic affiliates were over-leveraged as compared to the foreign affiliates.

\subsubsection{The 2013 Grubert/Altshuler proposal}

In their 2013 article, Grubert and Altshuler considered the relative merits of different reform proposals, including a full inclusion system (full taxation of foreign earnings); a dividend exemption for foreign earned dividends plus US tax on foreign (deductible) royalties, with passive income and other income taxed under subpart F; a variation on a full inclusion/territorial system that would take the foreign country's tax rate into account; and a minimum tax on foreign earnings. They also considered whether as an alternative to major reform, a simple repeal of the CTB rules could be sufficient to address many of the problems with the US international tax system.

\subsection{Evaluating the alternatives}

Grubert and Altshuler evaluated the different reform proposals according to how well they addressed the major concerns they had identified: lockout (in 2013, 
calculated to be $\$ 1.7$ trillion, by 2017 , approximately $\$ 3$ trillion) (Joint Committee on Taxation, 2017); income shifting; efficient worldwide allocation of capital; all else being equal, maximizing the taxes paid to the US rather than foreign governments; ensuring that the benefits of any tax reform were distributed proportionately across companies and industries; complexity; incentives for additional tax planning; and reducing incentives for US companies to expatriate. ${ }^{5}$

\subsection{The winner and runner-up}

Based on these metrics, Grubert and Altshuler concluded that a system with a percountry minimum tax with expensing would be preferred, because it offset (at least in part) increased incentives for income shifting that would otherwise result from a pure dividend exemption system. They suggested that a per-country minimum tax with a 15 percent tax on active income and a credit for foreign taxes paid up to the 15 percent threshold could be the best way to address problems with the US system, and considered a minimum tax to be preferable to less aggressive reforms (such as repeal of CTB regulations) because it would more effectively discourage income shifting and encourage low-tax countries to raise their tax rates (given that the USA would simply collect any extra tax revenue on profits from low-taxed jurisdictions). The authors argued that a per-country minimum tax with expensing for real investment was better than a full inclusion system because companies earning no more than a normal return shouldn't face an additional US tax (Grubert \& Altshuler, 2013).

Grubert and Altshuler also concluded that a minimum tax was more advantageous than such extreme alternatives as dividend exemption or full inclusion, with fewer of the negative consequences. While income-shifting incentives would effectively disappear if the US adopted a full inclusion system and adoption of a territorial system had the potential to increase the incentives for income shifting, they felt that both these challenges could be counterbalanced by a minimum tax. Grubert and Altshuler acknowledged that increasing US taxes on US companies' foreign income could potentially exacerbate the inversion problem (endemic in 2013), but argued that incentives to expatriate could be partially offset by eliminating lockout and simplifying the system. As a variation to the per-country minimum tax, they identified as a potential alternative an overall minimum tax on active foreign income with a credit for the overall effective foreign rate, and concluded that such a system could also provide substantial benefits, although it might not provide as strong protections against income shifting as a per-country system.

\footnotetext{
5 The topic of inversions was receiving a lot of media attention around this time. See, e.g., Martin Sullivan, Another Pharmaceutical Inversion to Ireland; More on the Horizon, 71 TAX Notes InT'L 597 (AUG. 12, 2013); Martin Sullivan, Eaton Migrates to Ireland: Will the U.S. Now Go Territorial? 66 TAX Notes Int'L 1090 (June 18, 2012); David Gelles, New Corporate Tax Shelter: A Merger Abroad, N.Y. TIMES (Oct. 9, 2013) at B1; Bret Wells, Cant and the Inconvenient Truth about Corporate Inversions, 136 Tax Notes 429 (2012); John D. McKinnon and Scott Thurm, U.S. Firms Move Abroad to Cut Taxes: Despite'04 Law, Companies Incorporate Overseas, Saving Big Sums on Taxes, Wall St. J., (Aug. 28, 2012), https://www.wsj.com/articles/SB1000087239639044423050457761523260210753.
} 


\section{The TCJA: Policy advice gone wrong?}

\subsection{The TCJA: major international provisions}

The international tax reform passed by Congress in 2017 closely tracks the recommendations from Grubert \& Altshuler's, 2013 article and shares many similarities, but also important differences, with other reform proposals advanced in the prior decade. The key changes to the US tax system introduced by the TCJA relevant to cross-border investment include the following.

\subsubsection{Reduction of the corporate tax rate}

The TCJA reduced the top corporate tax rate from 35 percent to a flat 21 percent rate (H.R. 1 (2017)), a rate far lower than suggested (or projected) by policymakers or most politicians. This change affects both purely domestic companies as well as multinationals, but has especially important implications in the international arena because cross-border investment decisions are made in the context of comparing rates across countries.

By leveling the playing field across countries, the sharp reduction in the US rate minimizes the benefits of earning income in other jurisdictions and so addresses income-shifting concerns. Bringing the US rate in sync with the rate in the rest of the world was intended to minimize tax-induced distortions in investment decisions.

\subsubsection{One-time deemed repatriation tax}

The TCJA imposed a one-time tax on the previously untaxed foreign earnings of 10-percent owned foreign companies (H.R. 1 (2017)). The rate of tax varied depending on whether the earnings were invested in cash (or cash equivalents) or non-cash assets, and companies could elect to pay the tax over 8 years.

By subjecting approximately $\$ 3$ trillion of US multinationals' earnings to immediate US tax, meaning that these earnings could be repatriated without additional federal income tax cost, the TCJA addressed the lockout effect.

\subsubsection{Participation exemption}

New Internal Revenue Code (IRC) section 245A provided US corporate shareholders with a 100 percent DRD for dividends paid from 10-percent owned foreign corporations. But the US adopted a territorial tax system only in a limited fashion: the DRD can only be claimed by corporate shareholders, and the exemption for foreign earnings only applies to dividends and not to gain from sales of stock or branch earnings. Participation exemption benefits are further limited 
because practically all CFC earnings are immediately taxable to their US shareholders under the expanded subpart F regime.

Because the DRD generally eliminates US tax on repatriation of funds it in theory reduces the incentives that led to lockout. But the limitations on the DRD also dilute its ability to meet its objectives.

\subsubsection{Partial repeal of indirect foreign tax credit}

The TCJA eliminated US corporate shareholders' ability to claim an indirect foreign tax credit upon receipt of dividends from foreign companies. Indirect foreign tax credits remain creditable in connection with inclusions mandated by subpart $\mathrm{F}$ and of global intangible low-taxed income (GILTI).

\subsubsection{Expansion of subpart $F$}

The TCJA significantly expanded the provisions under which US shareholders of CFCs are required to include a portion of their earnings into US taxable income in the year earned with the creation of a new category of income (GILTI) essentially equal to all of a CFC's earnings in excess of a 10 percent return on tangible asset basis. The income is taxed at a lower rate than the standard rate, due to a deduction allowable under new section 250, and may be offset by foreign tax credits, limited to 80 percent of foreign taxes paid attributable to the earnings giving rise to the inclusion. Taxes attributable to GILTI earnings are only creditable against GILTI inclusions and are ineligible for carryover. The conference report suggests that the maximum US tax rate on GILTI should be 13.125 percent, but because of the application of expense allocation rules the effective rate is often higher (REG-104390-18; Caballero \& Wood, 2018; Comments, 2019).

The GILTI provision, which subjects most of the earnings of CFCs to current US tax, reduces incentives to keep earnings offshore and like other provisions of the law, addresses lockout concerns. By subjecting much of the foreign earnings of US companies to immediate US tax, it also reduces the motivation for income shifting. Imposing immediate tax on foreign earnings should also in theory minimize taxinduced distortions in the decision to invest in the USA or overseas.

\subsubsection{Reduced tax on foreign-derived intangible income}

The TCJA allows domestic corporations a deduction equal to a percentage (37.5 percent deduction beginning in 2018 , decreasing to $21.875 \%$ in 2026) of their foreign-derived intangible income (FDII). Income may qualify as FDII if it is derived from sales by a US corporation to a non-US person for foreign use or from services provided to any person, or with respect to property, not located in the USA. The rate on FDII is supposed to be equivalent to the global effective rate on GILTI for foreign earnings of CFCs when taking into account the foreign tax credit and limitations. Like GILTI, the base of income from which the FDII is calculated exempts a return for qualified tangible property, but because for FDII the amount is based off 
of investment in tangible assets in the USA, greater investment in tangible assets reduces the amount of the benefit.

The FDII deduction, by reducing the incentives for US companies to migrate intellectual property offshore, addresses the more substantive aspects of income shifting and leads to more efficient and less distortive decisions about where to invest capital. New tools given to the IRS to address tax minimization strategies for outbound transfers of intellectual property are intended to address similar concerns (Joint Committee on Taxation, 2018).

\subsubsection{BEAT}

The TCJA imposes a wholly new tax — designed as a minimum tax —on the income of corporations that make what are considered excessive base eroding payments to related parties, at a rate of $10 \%$ on an expanded base that includes otherwise deductible base eroding payments (Cummings, 2018).

The base erosion and anti-abuse tax (BEAT) makes it less likely that companies will engage in purely tax-motivated inbound planning and so addresses the incomeshifting concern.

\subsubsection{Interest expense limitation}

The TCJA vastly expanded the law's interest expense limitation to almost all taxpayers other than small businesses, limiting deductions for net interest expense to $30 \%$ of adjusted taxable income (ATI) for the year, with the disallowed amount eligible for a carryforward. The base on which the limitation changes in 2022 to make the limitation more restrictive (Joint Committee on Taxation, 2019). Although this change applies to both domestic taxpayers and multinationals, it is especially targeted at foreign-headquartered companies who used leverage as a simple but effective means of reducing the US tax burden on their inbound investments.

By making it harder to over-leverage members of a multinational group, the interest expense limitation addresses concerns with the tax avoidance associated with income shifting through intercompany debt.

\subsubsection{Miscellaneous}

TCJA includes two new rules that restrict tax benefits otherwise allowable with respect to payments to or from hybrid entities or on hybrid instruments. ${ }^{6}$ Like other new limitations on deductions for cross-border payments, the anti-hybrid rules address income shifting across borders.

\footnotetext{
6 The DRD is not available for payments with respect to which the payor CFC received a deduction or similar tax benefit (this rule also applies to treat as subpart $\mathrm{F}$ income hybrid dividends among CFCs). New section 267A denies deductions for interest or royalty payments made to/from a hybrid entity or on a hybrid instrument.
} 
Other changes include a number of measures intended to limit some cross-border planning, such as modification of the attribution rules for purposes of determining when a company qualifies as a CFC; changes to the sourcing rules for export income (via an amendment to section 863b); and penalties applicable to inverted companies. $^{7}$

\subsubsection{TCJA changes: ideals and realities}

In principle, the TCJA addressed many of the most pressing concerns with the pre2017 US international tax regime, and many of the changes it introduced closely paralleled leading economic proposals. Detailed economic evaluation of how the TCJA has affected incentives for real cross-border investment and tax-motivated cross-border planning remains preliminary, and any attempt to measure the longterm impact of the reform will necessarily be subject to COVID-19 fiscal effects. Nonetheless, preliminary analyses indicate a disconnect between the ideals of the TCJA's international changes and the reality of what they accomplished. The analysis below considers the changes to the tax code made by TCJA within the framework of the objectives and proposals described in Grubert and Altshuler (2013).

\subsubsection{Addressing lockout}

The TCJA rendered approximately $\$ 3$ trillion of US multinationals' earnings subject to immediate US taxation, and going forward the participation exemption combined with GILTI should reduce the incentives for US companies to retain earnings offshore. But to date, a much smaller amount of funds was repatriated than was held offshore at the end of 2017.

Bureau of Economic Analysis balance of payment data through Q4 2019 indicates that approximately $\$ 1.04$ trillion was repatriated in the 2 years since TCJA's passage (Pickert, 2019), with the largest amount paid as dividends in the year after TCJA's enactment (approximately $\$ 780$ billion in 2018). While these amounts are large, they are less than 1/3 of pre-TCJA offshore earnings and of amounts projected to be repatriated (Morgan Stanley Research, 2019). In contrast, the 2004 temporary repatriation benefit resulted in repatriation of almost $1 / 2$ the estimated $\$ 750$ billion of overseas earnings at the time (Smolyansky et al., 2019).

Expectations that the tax on accumulated earnings and the repeal of the tax on foreign dividends would open the floodgates for US companies to access their foreign cash may have glossed over the realities and complexities inherent in extracting cash dividends from foreign operations. Among the hurdles to accessing foreign cash are tiers of intermediate holding companies with associated tax leakage on dividends and withholding taxes, local statutory financial requirements, currency gains, and uncertainty in the application of US federal and state tax rules. Much of

\footnotetext{
7 For example, TCJA increased the excise tax on compensation of executives of an expatriated company; the transition tax is increased for companies that expatriate within 10 years of enactment of the law; and there is an expanded definition of BEAT base eroding payments for expatriated entities.
} 
the amounts described by US companies as offshore earnings also may have been invested in operating assets that needed to be liquidated in order to release cash for distribution.

The additional (non-US federal income tax) costs of repatriating cash are illustrated in corporate financial accounts of companies such as eBay, which estimated a 24 percent cost to repatriating its foreign earnings, Cognizant Technology Solutions, which estimated a cost of $21 \%$, and Johnson \& Johnson, which indicated a potential cost of $2.5 \%$ of its effective rate (Herzfeld, 2018b). What emerges from the disconnect between policy proposals to eliminate the lockout effect and the amounts of cash repatriated is a better understanding of the obstacles that impede multinationals from having free access to overseas earnings, including the interplay with accounting rules on ancillary repatriation costs (Nichols et al., 2019).

The reality also diverges from policymakers' goal that foreign cash be used for domestic investment. The data suggest that repatriated funds were used primarily for stock buybacks. Stock buybacks undertaken by US companies with large amounts of overseas cash more than doubled from the Q4 2017 to Q1 2018 (from \$23 to \$55 billion). But after eliminating Apple from these statistics, the value of buybacks in Q1 2018 was no larger than in Q4 2016, presenting a murkier picture. Removing the 5 firms with the largest value of 2018 buybacks smooths out the numbers (Hanlon et al., 2019; Smolyansky et al., 2019). The reports on use of cash for stock buybacks also don't attempt to draw any correlation between buybacks and future US investments.

In any case, the data may be so company specific that it is difficult to draw aggregate conclusions. Beyer et al. (2021) looked at individual company data and concluded that how companies' spending and investment behavior responded to TCJA depended on a number of factors including their liquidity, investment opportunities, and borrowing costs. While companies with low domestic liquidity and high domestic investment opportunities increased their domestic capital expenditures (as well as their share repurchases), companies with low domestic liquidity and low domestic investment opportunities increased dividends. In contrast, companies with low domestic investment opportunities and high cost of debt reduced their outstanding debt.

The conclusion as to whether TCJA should be considered to have addressed the lockout problem is partly a matter of perspective. While more cash has been brought back than likely would have been in the absence of the law change, the amounts repatriated were less than expected, and repatriated funds were not necessarily invested in line with the goals of increasing domestic investment. The 2020 data also suggests a more positive picture. With an additional $\$ 400$ billion repatriated in a pandemic year (and over $\$ 100$ billion in Q1), more than double the amount from 2017 , it suggests that the new tax laws provided companies with greater ability to access cash when most needed.

\subsubsection{Income shifting}

It is difficult to grasp the extent to which the TCJA effectively addressed concerns over income shifting, in part because the increase in immediate taxation of foreign 
earnings was offset by the overall lower statutory rate. The fact that there remains a differential between the tax rate on domestic and foreign earnings suggests that while TCJA may have reduced, it probably didn't eliminate, incentives to move profits out of the USA. Furthermore, because GILTI is imposed on aggregated foreign earnings, room for income shifting among non-US jurisdictions planning remains (Clausing, 2020). In sum, while the TCJA made profit shifting less beneficial for US multinationals, the incentives for profit shifting remain (Beer et al., 2018; Dharmapala, 2018; Heinemann et al., 2018).

U.S. multinationals' decisions of where to locate profits are dependent on numerous factors including whether business operations are located in high-taxed or lowtaxed countries and the location of tangible investment (Sullivan, 2019). Analysis of at least some companies' financial statements does indicate that GILTI is having an impact on multinationals' effective tax rates; while some technology and pharmaceutical companies had effective rates on foreign earnings in the single digits pre-TCJA, after 2017, that's no longer the case (Donohoe et al., 2019). Dyreng et al. (2020) analyzed the effective tax rates of a large sample of US companies, concluding that TCJA provided more tax benefits to purely domestic firms than multinationals. Their results suggest that multinationals didn't benefit equally from the statutory rate reduction, perhaps reflecting reduced opportunities or lower incentives for income shifting. But Clausing (2020) and others have suggested that the TCJA contains continued incentives for income shifting because the foreign tax credit on GILTI is calculated on a combined basis.

\subsubsection{Efficient worldwide allocation of capital}

Whether TCJA resulted in a more efficient allocation of capital worldwide is a difficult question to analyze comprehensively. Unlike in the case of share buybacks, there was no obvious spike in investment among the top 15 cash holders in Q1 2018 relative to the previous quarter. But this data could simply be an indication that these companies didn't face significant cash constraints pre-TCJA. And while the largest use of repatriated cash was for stock buybacks, repatriated funds were also used for increased spending on research and development and capital expenditure (Smolyansky et al., 2019). The noisy data may result from the fact that a significant portion of cross-border trade and investment is attributable to just a small group of non-capital constrained companies (Freund \& Pierola, 2015; Davies et al., 2021). Separately, it is also difficult to determine the extent to which corporate statements regarding the use of repatriated funds were influenced by political and publicity factors (Morgan Stanley Research, 2019). One study has shown that neither number of employees nor companies' capital expenditure ratio was impacted by the 2017 corporate tax changes (Cohen \& Viswanathan, 2019).

Simply tracking the use of repatriated funds from individual company data or announcements may not tell the whole story, because government data isn't able to identify how shareholders that receive cash from stock buybacks use those funds-some of it may be reinvested in other businesses (Smolyansky et al., 2019). The law's complexity may be another factor influencing decisions about whether to increase capital expenditures, change investment locations or 
restructure operations (Chalk et al., 2018). A Congressional Research Service (CRS) paper concluded that the TCJA's effects on efficiency and optimality are mixed, while also suggesting that the TCJA would be unlikely to have a significant impact on the location of investment (Gravelle \& Marples, 2017).

Part of the reason it is difficult to determine whether the TCJA has resulted in a more efficient worldwide allocation of capital (or may do so in the future) is due to its complexity and how the different provisions interact. In particular, the exemption for the normal return from GILTI may incentivize (at the margins) investment overseas, an incentive which could be exacerbated because the parallel exemption in the case of FDII reduces the tax benefit for tangible assets owned in the USA (Congressional Budget Office, 2018). Companies' decisions as to where to invest depend on both on the rate of return earned on tangible assets and the foreign tax rate (Gravelle \& Marples, 2017).

Some have warned that the incongruities in GILTI's design may lead to US companies becoming tax-preferred buyers of routine foreign tangible assets (Smolyansky et al., 2019), and that the costs imposed by GILTI may result in deadweight losses (Dharmapala, 2018). But to the extent that TCJA's international provisions may incentivize more investment in tangible assets overseas, they may also create incentives to locate more in intangible assets in the USA (Gravelle \& Marples, 2017; Chalk et al., 2018). Increased incentives for US investment may be counterbalanced by the BEAT tax (Chalk et al., 2018).

While the TCJA, by lowering the marginal effective tax rate for US investments, may result in more domestic investment, whether that ultimately reduces investment in other countries may depend on the extent to which companies are capital constrained as well as other factors (Chalk et al., 2018). Beyer, Downes, Mathis and Rapley (2019) suggest that companies with high pre-TCJA repatriation costs have a relatively greater increase in foreign property, plant, and equipment investments after the law change than previously, meaning that the TCJA could be distorting investment location decisions in unexpected ways.

In a study that looked specifically at domestic acquisitions, Atwood et al. (2020) concluded that US companies that were likely to face TCJA repatriation taxes increased their announcements of domestic acquisitions post-TCJA, proportionately to the magnitude of their pre-TCJA repatriation tax increase, and that the increased likelihood and number of US and foreign target acquisition announcements were highest among companies with greater potential repatriation taxes prior to TCJA, with the increases driven by companies that held larger amounts of foreign cash before 2018. Post-TCJA, US companies likely to have GILTI inclusions increased their foreign target acquisitions compared to those companies not likely to have GILTI inclusions.

In short, the exclusion for the normal return on tangible assets overseas, together with the disallowance of a corresponding benefit for domestically owned assets, has resulted in some counterintuitive incentives for the location of tangible investments, including corporate acquisitions (Singh \& Mathur, 2019). For some assets and for some companies, the TCJA will result in a more efficient worldwide allocation of capital. But for other companies, and for other types of assets, the opposite effect could prevail. 


\subsubsection{Matching benefits and costs (for individual companies)}

Expectations that the law would benefit domestic companies more than multinationals were evidenced by stock market reactions leading up to and immediately after passage of the TCJA. (Morgan Stanley Wealth Management, 2017). The stock market reaction is borne out by preliminary analysis based on stock market pricing, financial statements, and earnings calls, all of which indicate that companies with a greater percentage of domestic relative to foreign earnings, and relatively smaller shares of earnings from intellectual property, disproportionately benefited from TCJA. Wagner et al. (2018) illustrate how "predictions on how the TCJA would differentially impact firms are borne out by actual stock price movements." Other evidence of which companies expected to benefit the most from TCJA changes comes from corporate press releases, as companies that had the highest pre-TCJA tax rates, and that expected their tax rate to decrease the most, were more likely to announce worker-related benefits due to the TCJA. Banks, retail establishments, and transportation firms-all industries with a high proportion of domestic relative to foreign earnings-were especially likely to announce employee-related benefits associated with tax reform (Hanlon et al., 2019). Companies with the highest pre-reform tax rates were more likely to assert they would invest more as a result of the TCJA (Hanlon et al., 2019). Collectively, these analyses suggest that the TCJA provided disproportionately greater benefits to US companies investing in US businesses. Dyreng et al. (2020) show that while the GAAP effective tax rate of purely domestic companies went down by 12.3 percentage points after TCJA, the decrease for multinationals was only 10.7 points. The difference is even greater when looking at cash tax rates.

There's an overlap between companies claiming benefits from the FDII deduction and those that claimed the domestic production activities benefit repealed by TCJA. Dowd and Landefeld (2018) have demonstrated the parallels between the recipients of prior export subsidies (and their replacement, the IRC $\S 199$ deduction) and the beneficiaries of the FDII deduction, notwithstanding that the stated goals and mechanics of the provisions are different. Estimates are that the top one percent of companies that claim an FDII benefit realized 85 percent of the total (Dowd \& Landefeld, 2018).

Other provisions of the TCJA also have resulted in disproportionate benefits for different industries. For example, the BEAT provides a specific exemption for cost of goods sold, which benefits companies that profit from the sale of goods, but there is no parallel exception for income from services. As a result, the BEAT hurts services companies relative to manufacturers (National Foreign Trade Council, 2019).

In conclusion, the TCJA likely disproportionately impacted—both positively and negatively-some types of companies relative to others. Given that a significant goal of the new law was to reduce income shifting by multinationals, it may be consistent with its policy goals that multinationals bore more of the costs of the new law. But other disparate impacts appear unintended. 


\subsubsection{Complexity}

The TCJA generally increased the complexity of the US international tax rules, rather than simplifying them (Fleming et al., 2018; Davis, 2019), and required thousands of pages of regulatory guidance. Part of the complexity derives from the fact that new regimes were simply layered on top of the old. The provisions intended to limit base erosion and profit shifting — such as new foreign tax credit baskets, antihybrid rules, the BEAT and the interest expense limitation, also introduced added complexity.

While one source of complexity is the inherent difficulty of the provisions, the law's complications are also due to the speed in which it was enacted, and so some of them may have been avoidable. The phase-outs embedded in the law, required to fit its cost within the budget window, will require ongoing monitoring, and the resulting lack of stability hinders planning and creates timing distortions (Chalk et al., 2018; Hariton, 2019).

The complexity has real-world consequences, aside from the cost of compliance (Lawless, 2013). The uncertainty it has created over its interpretation and whether it would survive a change in administration means that businesses are less likely to change investment behavior and location decisions as desired (Chalk et al., 2018).

\subsubsection{Incentives for additional tax planning}

While some provisions in the new law reduce taxpayers' ability to achieve lower rates by shifting assets and income overseas, thereby minimizing planning opportunities, it also created additional incentives for planning, such as by increasing the benefits to be gained from operating in branch rather than corporate subsidiary form (Donohoe et al., 2019).

The TCJA changed the planning paradigms with which both US and foreign multinationals were familiar, but there are indications that businesses are able to plan around the law's additional costs. The most obvious planning opportunities arise in connection with the BEAT, in part because of its cliff effect-the BEAT tax only applies if a company makes a specified percentage of base eroding payments relative to overall payments. Financial statement data as well as corporate statements indicate that companies are spending considerable resources to plan around the BEAT (Rubin, 2018; Athansiou, 2019; Crowell \& Moring, 2018), and that at least some are able to do so by restructuring legal and operational activities. For example, in response to the BEAT, many US insurance companies terminated intracompany reinsurance contracts (BEA, 2021; Hariton, 2019), and financial company Jeffries restructured to avoid negative consequences of the TCJA including the BEAT. Arguably, such changes are consistent with the law's intent of disincentivizing outbound payments to related parties.

GILTI is harder to plan around as it may require real investment in tangible assets (Beer et al., 2018) or triggering subpart $\mathrm{F}$ income, which is exempt from GILTI (Dharmapala, 2018; Donohoe et al., 2019) to allow for $100 \%$ foreign tax credit. Earnings calls and quarterly and financial statements provide other evidence of tax planning undertaken to avoid negative impacts from the TCJA. Companies including 
Qualcomm, McKesson, and Microsoft have indicated that they repatriated intellectual property post-TCJA (Donohoe et al., 2019; Horst, 2020) to take advantage of US tax benefits on FDII. But here too, planning may be characterized as a desired outcome of reform. That taxpayers are planning into structures that subject foreign earnings to full US taxation may provide a stronger indication that the law is meeting its objectives than that it's facilitating abusive planning.

In short, in many cases it is hard to separate out investment decisions that the law was deliberately designed to encourage from planning that contradicts the law's intent.

\subsubsection{Changes in the incentive to expatriate}

Among the TCJA's features that reduce US companies' incentives to invert are the reduction in the corporate tax rate, the interest expense limitation and the BEAT. But other provisions of the TCJA still make it more advantageous overall to be a foreign parented company, most important of which is the GILTI, because no other country imposes a worldwide minimum tax (Dharmapala, 2018; Factor et al., 2017; Krause \& Spinowitz, 2019).

While the decade prior to enactment of TCJA saw a spike in US companies inverting overseas, since the enactment of TCJA, there have been virtually no highprofile inversions announced. One exception, Dana, Inc., which in March 2018 announced that it was planning on moving its headquarters to the UK, eventually dropped the plan (Dawson \& Francis, 2018). The fact that Dana's announcement is the exception to the rule indicates that TCJA has been effective in this regard. While curtailment of the inversion trend may be attributed as much to Obama-era regulations as to the TCJA changes (Marples \& Gravelle, 2017; Pomerleau, 2018), some cross-border deals have resulted in US-headquartered companies, a phenomenon virtually unheard of in the year immediately prior to the TCJA's passage. ${ }^{8}$ For example, Mylan NV, a Dutch company that was the result of an expatriation, moved back to the USA when merging with a division of US pharmaceutical company Pfizer as Viatris Inc.

\subsubsection{Revenue}

The TCJA clearly resulted in a decrease in corporate tax revenues-from a pre-TCJA projection by the Congressional Budget Office of $\$ 340$ billion to FY 2018 revenue of $\$ 205$ billion, but this is attributable more to the significant decrease in the corporate rate than to the international law changes. Trump administration officials had

\footnotetext{
8 See Amanda Athanasiou, Inverters Return to the U.S., and Not Just for the Tax Rate, 95 TAX NotES INT'L 758, 758-759 (Aug. 19, 2019) (discussing AbbVie's plan to remain a domestic company after its acquisition of Irish company Allergan, and the combination of Pfizer's Upjohn division with Mylan into a US parented company).
} 
argued that the corporate rate reduction should result in no net revenue loss because it would result in greater economic growth. ${ }^{9}$

But the international provisions were projected to be, and appear to have been, net revenue raisers. For example, the transition tax has been estimated to have generated revenue of approximately $\$ 350$ billion (Congressional Budget Office, 2018), and, in excess of projections of approximately $\$ 100$ billion over 10 years, a Joint Committee on Taxation review of 81 companies that represent $1 / 4$ of all corporate earnings for 2018 showed GILTI tax liability for those companies in that year of $\$ 6$ billion (Joint Committee on Taxation, 2021).

\section{Conclusion}

In his 2018 book Advice and Dissent: Why America Suffers When Economics and Politics Collide, economist Alan Blinder argues that policymaking would be improved if it relied more heavily on technocrats, that economists have little influence on policy, and that the reason the tax code is a disgrace is because it was created by politicians rather than economists. But understanding how the principled policies which served as the basis for the TCJA's international reforms produced results often inconsistent with those principles suggests that a more nuanced understanding of how policies-even ones developed from sound principles-may work once they're enacted into law is warranted. TCJA's international provisions were heavily indebted to policy proposals developed from serious economics research and after careful evaluation of alternatives and many of the provisions enacted closely mimicked ideas touted by economists as solutions for widely identified problems with US international tax rules. Politicians relied heavily on economists' ideas in crafting reforms of US international tax rules, but the results still fail to match lofty goals.

What lessons can be learned from the large gap between predictions of the benefits of reform and the reality? One may be that incremental changes may be better than major ones. A second may be that it is not enough to agree on broad outlines and concepts when undertaking reform - the details of law changes matter. A third is that even if there's agreement as to the benefits of specific provisions, the complex interaction with both existing and newly introduced rules can also have unexpected consequences. Finally, adopting major tax changes without bipartisan buy-in creates uncertainties that limit their effectiveness. The story of the 2017 US international tax reform, its antecedents and consequences, should flash warning lights for global policy makers also considering major overhauls of existing regimes. Regime change in the international tax area is harder than it looks.

\footnotetext{
9 See, e.g., Background Press Call on the Impact of the Tax Cuts and Jobs Act, whiteHousE.gov (Apr. 12, 2019), https://www.whitehouse.gov/briefings-statements/background-press-call-impact-tax-cuts-jobs-act/ ("if you continue drawing 1 percent higher than people thought was possible for a decade, then you've got 10 percent more GDP. If you look at GDP out in the 10th year, then that means that you're going to have about $\$ 3$ trillion more GDP in that year alone, and so therefore it's very easy to conceive of scenarios where you end up with a lot more revenue than was projected before the tax cuts were passed."); Remarks by CEA Chairman Kevin Hassett at the Japan Center for Economic Research, 2018 TAX NotES TodAY 151-36 (Aug. 3, 2018).
} 
Acknowledgement Helpful comments on earlier drafts were received from Rosanne Altshuler, Ron Davies, Robert Dilworth, Peter Merrill, Paul Oosterhuis and participants in the 2020 Annual Congress of the International Institute of Public Finance online. Jacob Markham provided helpful research assistance.

\section{References}

Athansiou, A. (2019). Semiconductor giant restructures to avoid BEAT, GILTI. Tax Notes International, 93, 579-580.

Atwood, T. J., Downes, Jimmy, Henley, Jodi and Mathis, Mollie (2020). The Impact of U.S. tax reform on U.S. firm acquisitions of domestic and foreign targets. http://dx.doi.org/https://doi.org/10.2139/ ssrn.3600978.

Avi-Yonah, R. (2005). All of a piece throughout: The four ages of U.S international taxation. Virginia Tax Review, 25, 313-338.

Avi-Yonah, R. (2006). The three goals of taxation. Tax Law Review, 60, 1-28.

Avi-Yonah, R. (2018). How terrible is the new tax law? Reflections on TRA17. University of Michigan Public Law Research Paper No. 586, https://ssrn.com/abstract=3095830.

Avi-Yonah, R., \& Xu, H. (2017). Evaluating BEPS. Erasmus Law Review, 10, 3-11.

Beavers, O. (2017). Mnuchin: 90 percent of Americans will be able to file taxes on postcard. The Hill, https://thehill.com/homenews/administration/365306-mnuchins-americans-will-be-able-to-file-90percent-of-taxes-on.

Beer, S., Klemm, A., \& Matheson, T. (2018). Tax Spillovers from US Corporate Income Tax Reform. IMF Working Paper 18/166. https://www.imf.org/en/Publications/WP/Issues/2018/07/13/Tax-Spill overs-from-US-Corporate-Income-Tax-Reform-46055.

Better.gop (2016) A better way: Our vision for a confident America, available at 2016 Tax Notes Today (Jun. 24).

Beyer, B., Downes, J., Mathis, M., \& Rapley, E. (2019). The effect of the tax cuts and jobs act of 2017 on multinational firms' capital investment: Internal capital market frictions and tax incentives, UNC Tax Center. https://tax.unc.edu/index.php/publication/the-effect-of-the-tax-cuts-and-jobs-act-of2017-on-multinational-firms-capital-investment-internal-capital-market-frictions-and-tax-incen tives/.

Beyer, Brooke, Downes, Jimmy, Mathis, Mollie and Rapley, Eric T. (2021) Early evidence on the use of foreign cash following the tax cuts and jobs Act of 2017. http://dx.doi.org/https://doi.org/10.2139/ ssrn.3818149.

Blouin, J., Krull, L., \& Robinson, L. (2017). The location, composition, and investment implications of permanently reinvested earnings, https://ssrn.com/abstract $=2154662$.

Bureau of Economic Analysis, International Data U.S DePT. of Commerce (2021).

Caballero, M., \& Wood, I. (2018). Restoring a 'Not GILTI' verdict for high-taxed income. Tax Notes, $161,189-199$.

Congressional Budget Office. (2018). CBO's projections of federal receipts and expenditures in the national income and product accounts. https://www.cbo.gov/publication/54194 .

Congressional Budget Office. (2019). Budget and economic outlook: 2019 to 2029. https://www.cbo.gov/ system/files/2019-03/54918-Outlook-3.pdf

Chalk, N., Keen, M., \& Perry, V. (2018). the tax cuts and jobs act: An appraisal. IMF working paper no. 18/185. https://ssrn.com/abstract=3236801.

Christians, A. (2018). Introduction to Tax Policy Theory, https://papers.ssrn.com/sol3/papers.cfm?abstr act_id=3186791.

Clausing, K. (2011). The revenue effects of multinational firm income shifting. Tax Notes, 130, $1580-1586$.

Clausing, K. A. (2020). Profit shifting before and after the tax cuts and jobs act. forthcoming. National Tax Journal. https://doi.org/10.2139/ssrn.3274827

Cohen, Nicholas and Viswanathan, Manoj (2019). Corporate behavior and the tax cuts and jobs act (September 7, 2019). University of Chicago Law Review, Vol. Online, 2020. https://ssrn.com/abstract= 3449860 .

Comments on GILTI Regulations, 2019 TAX Notes Today 29 (Feb. 11, 2019) 
Congressional Budget Office. (2018). The budget and economic outlook: 2018 to 2028. https://www.cbo. gov/publication/53651.

Crowell \& Moring. (2018). Tax reform in small bites: Beating the BEAT. https://www.crowell.com/ NewsEvents/AlertsNewsletters/all/Tax-Reform-in-Small-Bites-Beating-the-BEAT-Base-Erosi on-and-Anti-Abuse-Tax

Cummings, J., Jr. (2018). Selective analysis: The BEAT. Tax Notes, 158, 1757-1771.

Davies, R., Siedschlag, I., \& Studnicka, Z. (2021). The impact of taxes on the extensive and intensive margins of FDI. International tax \& Public Finance, 28, 434-464.

Davis, C. (2019). Is the tax cuts and jobs act GILTI of anti-simplification? Virginia Tax Review, 38, 315-396.

Dawson, C. \& Francis, T. (2018). Despite U.S. Tax overhaul, Ohio-based dana considers a move abroad, wall street journal. https://www.wsj.com/articles/dana-to-take-over-gkns-automotive-drivelinebusiness-1520614366.

De Mooij, R., \& Ederveen, S. (2008). Corporate tax elasticities: A reader's guide to empirical findings. Oxford Review of Economic Policy, 24(4), 680-697.

Desai, M., \& Hines, J., Jr. (2003). Evaluating international tax reform. National Tax Journal, 56, 487-502.

Desai, M., \& Hines, J., Jr. (2004). Old rules and new realities: Corporate tax policy in a global setting. National Tax Journal, 57, 937-960.

Devereux, M. (2008). Taxation of outbound direct investment: Economic principles and tax policy considerations. Oxford Review of Economic Policy, 24, 698-719.

Dharmapala, D. (2018). The consequences of the tax cuts and jobs act's international provisions: Lessons from existing research. National Tax Journal, 71(4), 707-728.

Donohoe, M., McGill, G., \& Outslay, E. (2019). The geometry of international tax planning after the tax cuts and jobs act: A riff on circles, squares, and triangles. National Tax Journal, 72(4), 647-669.

Dowd, T., \& Landefeld, P. (2018). The business cycle and the deduction for foreign derived intangible income: A historical perspective. National Tax Journal, 71(4), 729-749.

Dyreng, S., Gaertner, F., Hoopes, J., \& Vernon, M. (2020). The effect of U.S. tax reform on the tax burdens of U.S. domestic and multinational corporations. https://dx.doi.org/https://doi.org/10.2139/ ssrn.3620102.

Edwards, A., Kravet, A., \& Wilson, R. (2016). Trapped cash and the profitability of foreign cash acquisitions. Contemporary Accounting Research, 33(1), 44-77.

Factor, J., Fedida, M., \& Wollman, D. (2017). Tax Cuts \& Jobs Act: Considerations for M\&A, Cleary Gottlieb. https://www.clearygottlieb.com/ /media/files/updated-tax-reform-12-27-17/tcja-summa ry--ma.pdf.

Fleming, J., Peroni, R., \& Shay, S. (2018). Expanded worldwide versus territorial taxation after the TCJA. Tax Notes, 161, 1178.

Freund, C., \& Pierola, M. D. (2015). Export superstars. Review of Economics and Statistics, 97(5), 1023-1032.

Frisch, D. (1990). The economics of international tax policy: Some old and new approaches. Tax Notes, 47, 581-590.

Graetz, M. (2001). Taxing international income - inadequate principles, outdated concepts, and unsatisfactory policy. Tax Law Review, 54, 261-336.

Graetz, M., \& O’Hear, M. (1997). The “Original Intent” of U.S international taxation. Duke Law Journal, $46,1021-1110$.

Gravelle, J. (2015). Tax havens: International tax avoidance and evasion. Congressional Research Service Report.

Gravelle, J. (2017). Base erosion and profit shifting (BEPS): OECD Tax Proposals. Congressional research service report.

Gravelle, J. \& Marples, D. (2020). Issues in international corporate taxation: The 2017 Revision (P.L. 115-97). Congressional research service report R45186. https://fas.org/sgp/crs/misc/R45186.pdf.

Grinberg, I. (2017). Testimony before the Senate Finance Committee. https://www.finance.senate.gov/ imo/media/doc/Grinberg\%20October\%202017\%20SFC\%20International\%20Tax\%20Testimony\% 20FINAL.PDF.

Grubert, H. (2012). Foreign Taxes and the growing share of U. S. Multinational company income abroad: Profits, not sales, are being globalized. National Tax Journal, 65(2), 247-281. 
Grubert, H., \& Altshuler, R. (2008). Corporate taxes in the world economy: Reforming the taxation of cross-border income. In J. W. Diamond \& G. R. Zodrow (Eds.), Fundamental tax reform: Issues, choices and implications (pp. 319-354). MIT Press.

Grubert, H., \& Altshuler, R. (2013). Fixing the system: An analysis of alternative proposals for the reform of international tax. National Tax Journal, 66(3), 671-712.

Grubert, H., \& Mutti, J. (2001). Taxing international business income: Dividend exemption versus the credit system. American Enterprise Institute Press.

Guild, B. (2017). Trump outlines tax overhaul goals, CBS News, https://www.cbsnews.com/news/trumptax-reform-speech-springfield-mo-live-updates/.

Hanlon, M., Hoopes, J., \& Slemrod, J. (2019). Tax reform made me do it! Tax Policy and the Economy, 33, 33-80. https://doi.org/10.1086/703226

Hariton, D. (2019). The heart of the beat. Tax Notes, 163, 677-693.

Heinemann, F., Olbert, M., Pfeiffer, O., Schwab, T., Spengel, C., \& Stutzenberger, K. (2018). Implications of the US tax reform for transatlantic FDI. Intereconomics, 53, 87-93. https://doi.org/10. 1007/s10272-018-0727-6

Herzfeld, M. (2017). The case against BEPS: Lessons for tax coordination. Florida Tax Review, 21, 1-59.

Herzfeld, M. (2018a). The Origins of GILTI. Tax. Notes, 159, 1870-1874.

Herzfeld, M. (2018b). Accounting disclosures post-TCJA. Tax Notes, 161, 1069-1073.

Hines, J. (1999). Lessons from behavioral responses to international taxation. National Tax Journal, 52(2), 305-322.

Horst, T. (2020). The TCJA's incentives for and impediments to repatriating intangible property. Tax Notes International, 97, 635-643.

Joint Committee on Taxation. (2011). Federal Tax treatment of individuals, JCX-43-11.

Joint Committee on Taxation. (2013). Report to the house committee on ways and means on present law and suggestions for reform submitted to the tax reform working groups, JCS-3-13.

Joint Committee on Taxation. (2015). Complexity in the federal tax system, JCX-49-15.

Joint Committee on Taxation. (Sept. 2017). Present Law and Selected Policy Issues in the U.S. Taxation of Cross-Border Income, JCX-45-17.

Joint Committee on Taxation. (Dec. 2017). Estimated budget effects of the conference agreement for H.R.1, The "Tax Cuts And Jobs Act", JCX-67-17.

Joint Committee on Taxation. (2018). General explanation of Pub. Law 115-97, JCS-1-18.

Joint Committee on Taxation. (2019). Overview of limitation on deduction of business interest: Section 163(j). https://www.jct.gov/publications.html?func=startdown\&id=5174

Joint Committee on Taxation. (2021). U.S. International tax policy: Overview and analysis, JCX-16R-21.

Kamin, D., et al. (2018). The games they will play: Tax games, roadblocks, and glitches under the 2017 tax legislation. Minnesota Law Review, 103, 1439-1521.

Kane, M. (2006). Ownership neutrality ownership distortions, and international tax welfare benchmarks. Virginia Tax Review, 26, 53-79.

Keightley, M. (2013). An analysis of where American companies report profits: Indications of profit shifting, congressional research service report 7-5700 R42927.

Keen, M., \& Wildasin, D. (2004). Pareto-efficient international taxation. American Economic Review, 94(1), 259-275.

Kleinbard, E. (2011a). Stateless income. Florida Tax Review, 11, 699-774.

Kleinbard, E. (2011b). The lessons of stateless income. Tax Law Review, 65, 99-171.

Kleinbard, E. (2017). Senators picked Americans' pockets via degraded tax policy process. The Hill. https://thehill.com/opinion/finance/363096-senators-picked-americans-pockets-via-degraded-taxprocess

Knoll, M. (2011). Reconsidering International Tax Neutrality. Tax Law Review, 64, 99-129.

Krause, B. \& Spinowitz, M. (2019). US Tax reform and cross-border M\&A: Considering the impact, one year In. Skadden's 2019 Insights. https:/www.skadden.com/insights/publications/2019/01/2019insights/us-tax-reform-and-cross-border-ma.

Kysar, R. (2018). Testimony before the Senate Finance Committee. Early impressions of the new tax law, https://www.finance.senate.gov/hearings/early-impressions-of-the-new-tax-law

Kysar, R. (2020). Testimony before the house ways \& means committee. The disappearing corporate income tax, https://waysandmeans.house.gov/legislation/hearings/disappearing-corpo rate-income-tax.

Lawless, M. (2013). Do complicated tax systems prevent foreign direct investment? Economica, 80(317), $1-22$. 
MacGuineas, M. (2019). The Tax cuts and jobs act made the debt worse and makes fixing it even harder, AEI blog (Oct. 22, 2019), https://www.aei.org/economics/ the-tax-cuts-and-jobs-act-made-the-debt-worse-and-makes-fixing-it-even-harder/.

Marples, D. \& Gravelle, J. (2017). Corporate expatriation, inversions, and mergers: Tax issues. congressional research service report 7-5700 R43568.

Minarik, J. Taxation, library of economics and liberty. https://www.econlib.org/library/Enc/Taxation. html.

Mirrlees, J., Adam, S., Besley, T., Blundell, R., Bond, S., Chote, R., Gammie, M., Johnson, P., Myles, G., \& Poterba, J. (2011). Tax by Design.

Morgan Stanley Research. (2019). Cash tracker: 2018 repatriation and investment trends.

Morgan Stanley Wealth Management. (2017). How corporate tax reform could affect earnings.

Musgrave, P. (1969). United States taxation of foreign investment income: Issues and arguments. Harvard Law School.

National Foreign Trade Council, Comments on BEAT Regulations (Feb. 19, 2019), available at 2019 WTD 50-18.

Nichols, N., Duxbury, D., Scott, I. (2019). Finalizing the TCJA's impact: 2018 Form 10-K adjustments analysis 164 TAX Notes FED. 463, 472 (Jul. 22, 2019).

OECD. (2013). Action plan on base erosion and profit shifting. http://dx.doi.org/https://doi.org/10.1787/ 9789264202719-en.

Offshore Profit Shifting and The U.S. Tax Code-Part 2 (Apple Inc.) Hearing Before the Subcommittee on Investigations of the Comm. On Homeland Security and Governmental Affairs United States Senate, 113th Congress, Senate Hearing, 113-90 (May 21, 2013).

Pickert, R. (2019). U.S. Companies' Repatriated Cash Hits \$1 Trillion Under Tax Law, Bloomberg (Dec. 19, 2019), https://www.bloomberg.com/news/articles/2019-12-19/u-s-companies-repatriated-cashhits-1-trillion-under-tax-law

Pomerleau, K. (2018). Inversions under the new tax law, tax foundation (Mar. 13, 2018), https://taxfo undation.org/inversions-new-tax-law/

REG-104390-18, 2018-43 IRB 671; 83 Federal Register 51,072-51,111 (2018).

Report of the President's Advisory Panel on Federal Tax Reform (2005), available at https://govinfo.libra ry.unt.edu/taxreformpanel/final-report/index.html

Richman, P. (1963). Taxation of foreign investment income: An economic analysis. Johns Hopkins Press.

Rubin, R. (2018). Companies hope to beat a new tax called the BEAT. Wall Street Journal. https://www. wsj.com/articles/companies-hope-to-beat-a-new-tax-called-the-beat-1530005401.

Senate Bill 2091, 112th Congress. (2012). https://www.congress.gov/bill/112th-congress/senate-bill/ 2091/text.

Shaviro, D. (2016). The crossroads versus the seesaw: Getting a "Fix" on recent international tax policy developments. Tax Law Review, 69, 1-42.

Sherlock, M. (2013). Tax reform in the 113th congress: An overview of proposals. Congressional research service report R43060. https://www.novoco.com/sites/default/files/atoms/files/tax _ reform_113_congress_proposals_010214.pdf.

Singh, K., \& Mathur, A. (2019). The impact of GILTI and FDII on the investment location choice of U.S. multinationals. Columbia Journal of Tax Law, 10(2), 199-224.

Slemrod, J. \& Bakija, J. (2017). Taxing ourselves ( $5^{\text {th }}$ ed.).

Smolyansky, M., Suarez, G., \& Tabova, A. (2019). U.S. Corporations' repatriation of offshore profits: Evidence from 2018. FEDS notes, board of governors of the federal reserve system. (Aug. 6, 2019), https://www.federalreserve.gov/econres/notes/feds-notes/us-corporations-repatriation-ofoffshore-profits-20190806.htm.

Stecker, J. (2018). Big changes for big businesses: The initial impact of tax reform on public corporations. Unpublished.

Sullivan, M. (2012). The economic case for unlocking foreign profits. Tax Notes International, 67, 102-106.

Sullivan, M. (2019). Quantifying the benefits of profit shifting under GILTI, Part 2. Tax Notes International, 95, 676.

The Bipartisan tax fairness and simplification act of 2011 (S. 727) Corporate Tax Fairness Act. (2013). (H.R. 694).

Treasury Department. (2017). Unified framework on tax reform. https://www.treasury.gov/press-center/ press-releases/Documents/Tax-Framework.pdf. 
Trump's tax reform happened, now what? AEI Blog, https://www.aei.org/trumps-tax-reform-happenednow-what/ [last accessed Dec. 29, 2019].

U.S. Department of Treasury. (2013). General Explanations of the Administration's Fiscal Year 2014 Revenue Proposals (Green Book). https://www.treasury.gov/resource-center/tax-policy/documents/ general-explanations-fy2014.pdf.

U.S. Department of Treasury. (2019) Monthly treasury statement. https://fiscal.treasury.gov/files/reportsstatements/mts/mts1119.pdf.

U.S. Senate Committee on Finance. (2013). Baucus unveils proposals for international tax reform. https:// www.finance.senate.gov/chairmans-news/baucus-unveils-proposals-for-international-tax-reform.

Wagner, A., Zeckhauser, R. \& Ziegler, A. (2018). Unequal rewards to firms: Stock market responses to the trump election and the 2017 corporate tax reform, AEA papers and proceedings 108, 590.

Ways and Means Discussion Draft. (2011). Tax Notes Today, 2011, 208-227.

Weisbach, D. (2015). The use of neutralities in international tax policy. National Tax Journal, 68, $635-651$.

Publisher's Note Springer Nature remains neutral with regard to jurisdictional claims in published maps and institutional affiliations. 